\title{
Impact of Global Change on Nutrient Dynamics in Mangrove Forests
}

\author{
Daniel M. Alongi ${ }^{(1)}$ \\ Tropical Coastal \& Mangrove Consultants, 6 Cobb Court, Annandale, QLD 4814, Australia; \\ dmalongi@outlook.com; Tel.: +61-7-47252545
}

Received: 31 August 2018; Accepted: 25 September 2018; Published: 25 September 2018

\begin{abstract}
The cycling of essential nutrients is central to mangrove productivity. A mass balance shows that mangroves rely on soil ammonification, nitrification, and dissimilatory reduction to ammonium for available nitrogen. Mangroves are often nutrient limited and show tight coupling between nutrient availability and tree photosynthesis. This relationship and, thus, forest productivity can be disrupted by various disturbances such as deforestation, changes in hydrology due to impoundments, land-use change, increasing frequency and intensity of storms, increasing temperatures, increasing atmospheric $\mathrm{CO}_{2}$ concentrations, and a rising sea-level. Deforestation and hydrological changes are the most devastating to soil nutrient-plant relations and mangrove productivity. Land-use changes can result in positive and negative impacts on mangroves and can also results in increasing frequency of storms and intensity of storms. Increasing temperatures and atmospheric $\mathrm{CO}_{2}$ levels have an initially enhanced effect on mangroves and microbial transformation rates of nitrogen and phosphorus. The effects of rising seas are complex and depend on the local rate of sea-level rise, the soil accretion rate, the subsidence or uplift rate, and the tidal position. If mangroves cannot keep pace with a sea-level rise, seaward mangroves will likely drown but landward mangroves will expand and show enhanced growth and more rapid nutrient cycling if space permits.
\end{abstract}

Keywords: climate change; disturbance; global change; mangrove; nitrogen; nutrients; phosphorus

\section{Introduction}

Mangrove forests and their associated waterways are dominant ecosystems in the subtropics and tropics and line most of the world's coastlines at low latitudes. Mangroves inhabit over $152,000 \mathrm{~km}^{2}$ of coastal area but occupy $<1 \%$ of the world's coastal zones [1,2]. These tidal forests are the only woody halophytes that live in salt water and provide a wide variety of ecological and economic goods and services [3]. They act as habitats for terrestrial and marine flora and fauna, as ecosystem engineers shaping and maintaining the intertidal zone, as a renewable resource of wood and fuel, and as key accumulation sites for soils, sediment particles, and associated elements [3].

Mangrove forests are the most productive plants in the sea with average rates of gross and net primary production of $4.6 \mathrm{~kg} \mathrm{C} \mathrm{ha}^{-1}$ year $^{-1}$ and $1.9 \mathrm{~kg} \mathrm{C} \mathrm{ha}^{-1}$ year ${ }^{-1}$, respectively [4]. These rapid rates of productivity drive high requirements for nutrients and trace elements to sustain growth, production, and physiological maintenance. These high requirements translate into rapid uptake of soil nutrients that are transformed by Archaea, bacteria, fungi, protozoa, and microalgae. There are tight links between carbon fixation and nutrient cycling [5].

Mangrove forests, living at the dynamic interface between land and sea, are subject to various disturbances that vary in time and space and occupy a harsh environment, which is daily subjected to tidal changes in temperature, water and salt exposure, and varying degrees of anoxia $[3,4]$. Mangroves are, thus, robust and highly adaptable to changing conditions [6]. A variety of features of mangroves contribute to their resilience to disturbance. These features are: (1) a large reservoir 
of below-ground nutrients that serve to replenish nutrient losses, (2) rapid rates of nutrient flux and microbial decomposition that facilitate rapid biotic turnover, (3) complex and highly efficient rates of water-use and nutrient-use efficiency that allow internal reuse of resources to augment recovery, (4) simple architecture that leads to rapid reconstruction and rehabilitation post-disturbance, (5) redundancy of keystone species, which can lead to restoration and recovery of key structures and function, and (6) negative and positive feedback that provides stability to help dampen changes in the ecological steady-state [3,6]. This is not to say that mangroves always recover from disturbances. Deforestation and impoundments are devastating for mangrove forests.

Mangroves are currently being strongly affected by various human-induced disturbances including increased sedimentation and nutrient inputs, impoundments, deforestation, increased frequency and intensity of storms, increasing temperatures, increasing atmospheric $\mathrm{CO}_{2}$, and a sea-level rise. Several reviews have focused on the impact of climate change on mangrove forests [6-8], but none have examined in detail the impact of both climate and various other disturbances on these tidal ecosystems. The object of this review is to critically assess the actual and potential impacts of global change on nutrient dynamics in mangrove ecosystems. The focus is on nutrient dynamics because of the close links between nutrients and mangroves and its centrality to mangrove ecosystem dynamics.

\section{Mangroves and Nutrients}

Mangroves present an apparent paradox in that they are highly productive and rich in carbon while nutrient-poor. Many studies of mangrove nutrition have focused on how mangroves can sustain high rates of productivity in the face of nutrient limitation [9]. Evidence to date suggests that high productivity in mangroves is achieved when nutrients limit growth through highly efficient nutrient cycling and nutrient retention mechanisms [10].

Owing to their estuarine and marine existence, mangroves are generally not limited by the relatively large quantities of sulfur, boron, potassium, magnesium, and sodium in seawater but are frequently limited by nitrogen and phosphorus. Iron and copper have been found to be limiting for mangroves in mesocosm studies [11,12]. The critical need for nitrogen and phosphorus has been repeatedly demonstrated in field and laboratory studies [9]. A key role in mangrove nutrition is the interactive effects between different nutrients and environmental factors such as salinity, soil type and texture, and frequency of tidal inundation. The effects of added nitrogen and phosphorus vary among species. Fertilization studies demonstrate either nitrogen or phosphorus limitation or both depending on species composition, the extent of terrigenous input, soil fertility and texture, the soil redox status, salinity, and the frequency of tidal inundation [13]. Plant-soil relations can be greatly disturbed by altering hydrology and the construction of impoundments. Flooding and draining of tidal waters are of prime importance on mangrove growth and nutrient use since tidal changes relate to an exchange of nutrients and other materials and to rates of sediment and nutrient input.

High photosynthetic rates by mangroves is supported by a high requirement for nutrients, which implies high nutrient-use efficiencies and high rates of leaf resorption. Nutrient-use efficiency for nitrogen in mangroves is, at the upper end of the range, for other tropical forests [4]. However, nutrient-use efficiency for phosphorus in mangroves is well within the range of values of other tropical forests [4]. Mangroves must be efficient to survive when living in oligotrophic, anoxic soils and waters and being continually inundated by tides. In such habitats, it is clearly advantageous to have mechanisms to conserve limiting nutrients. Efficient utilization of nutrients as an apparent strategy relates well to the generally low concentrations of nutrients in mangrove leaves and other tree parts and the generally high efficiency with which nitrogen and phosphorus are resorbed from leaves $[9,10]$.

Mangroves have other mechanisms to retain nitrogen and phosphorus including a large reservoir of dead roots and tight immobilization of available solutes [4]. Phosphorus is tightly immobilized to inorganic phases such as soil aluminum, iron, calcium, and sulfides and dissolved nitrogen in soil is mainly in the form of ammonium rather than nitrite and nitrate $[14,15]$. Residence times of the 
available nitrogen and phosphorus pools are short in keeping with the generally rapid rates of nutrient recycling [16].

There are species-specific differences in nutrient-use efficiency especially in arid-zone forests. In arid Western Australia, Alongi et al. [17] measured mean residence times for both nitrogen and phosphorus of 2-4 years in Rhizophora stylosa Griff. forests, whereas the residence times were shorter (<2 years) in Avicennia marina (Forsk.) Vierh. stands. These differences may reflect the fact that $A$. marina trees are more efficient at utilizing nitrogen and phosphorus solutes since $A$. marina soils are less anoxic than soils of $R$. stylosa. Other reasons may explain species differences in nutrient use such as differences in the way species allocate nutrients, differences in the proportion of energy and nutrients vested in chemical defenses, differences in leaf life spans, and differences in soil physico-chemistry and biogeochemistry [9].

Most mangrove trees are evergreen with sclerophyllous leaves and high root/shoot ratios. Sclerophylly is a trait related to low soil nutrient availability especially low phosphorus as well as to low water availability and to high-salinity environments since sclereophyllous leaves can lose much of their water content and can exhibit extremely low leaf water potentials [10]. Sclerophylly has also been linked to leaf longevity and to ecosystem nutrient retention. The capacity to sustain low growth rates and reduced nutrient requirements as mangroves do in arid or high-intertidal environments are an adaptation to low-nutrient habitats [18]. Mangroves have root/shoot ratios that are often an order of magnitude greater than those of tropical terrestrial forests. Such high root/shoot ratios are in part an adaptation to salty environments but can vary between mangrove species over time and with forest structure. This results in non-linear relationships between root/shoot ratios and soil conditions. The high root biomass in mangroves is generally conducive to nutrient capture and uptake from low-nutrient soils $[9,10]$.

The efficiency of soil microbial metabolic processes is also an effective nutrient conservation strategy. A large proportion of root respiration goes towards the uptake and assimilation of nitrogen especially ammonium. Ammonium is preferentially taken up when compared with nitrite and nitrate as the uptake of ammonium requires the least energy investment for mangroves [9,10]. As pointed out by Reef et al. [9], the large root biomass in mangroves may overcome the relative immobility of soil ammonium by the large volume of soil covered by the roots.

The nitrogen cycle is understood well enough to construct a preliminary global nitrogen budget (Figure 1). The budget [19] shows that (1) $2687 \mathrm{Gg} \mathrm{N}$ year $^{-1}$ is required to sustain mangrove net primary production, (2) nitrogen burial equates to about $25 \%$ of total nitrogen input, (3) nitrogen fixation is $<5 \%$ of total nitrogen input, (4) about $40 \%$ of nitrogen input required for total mangrove net primary production is vested in below-ground root production, (5) about $50 \%$ of nitrogen required for mangrove net primary production is vested in litter, (6) net tidal export equates to about $55 \%$ of nitrogen vested in mangrove net primary production, (7) $<10 \%$ of mangrove nitrogen is lost via denitrification and $\mathrm{N}_{2} \mathrm{O}$ emissions, and (8) nitrogen fluxes are in net balance since the net gain (351 $\left.\mathrm{Gg} \mathrm{N}_{\text {year }}^{-1}\right)$ is very small compared to total inputs and outputs and sources of error [19].

The mangrove nitrogen mass balance estimates, although preliminary, have some implications for the impacts of global change in mangroves. First, it is reasonably clear that most nitrogen to sustain mangrove net primary production is the net result of soil ammonification, nitrification, and/or dissimilatory nitrate reduction to ammonium. Global changes that affect rates of ammonification or dissimilatory nitrate reduction such as massive soil disturbance will likely have significant impacts on mangrove productivity. Second, soil microbial processes such as nitrogen fixation and denitrification and anammox play a comparatively small role in nitrogen dynamics in mangroves so factors that can change rates of such processes will probably have little impact on mangrove nitrogen dynamics. Third, a substantial fraction of total nitrogen input is buried in mangrove soils (Figure 1), which suggests that burial is a significant nitrogen conservation mechanism. Fourth, global changes that affect below-ground root production and plant litter will likely have a substantial impact on net primary productivity. Fifth, global changes that affect tidal exchange such as changes to hydrology 
and construction of impoundments will very likely have significant impacts on the balance of nitrogen dynamics of mangrove forests. Sixth, at present, nitrogen fluxes in mangrove ecosystems are roughly in overall balance. Global changes may enhance or negatively affect this balance and, thus, the survival of mangrove ecosystems. Some global changes such as temperature increases will likely have little impact on mangroves whereas some changes such as deforestation have a substantial impact.

In contrast, the cycling of phosphorus and other possible limiting nutrients such as iron and copper are poorly known in mangrove soil and waters. The phosphorus cycle is presumably tightly linked to soil geochemical processes and the low available phosphorus concentrations (phosphate, organic phosphorus) suggest low nutrient availability [15]. It is clear that more research is needed regarding the impact of disturbances on the cycling of phosphorus, iron, and copper and their interactions with soil geochemistry.

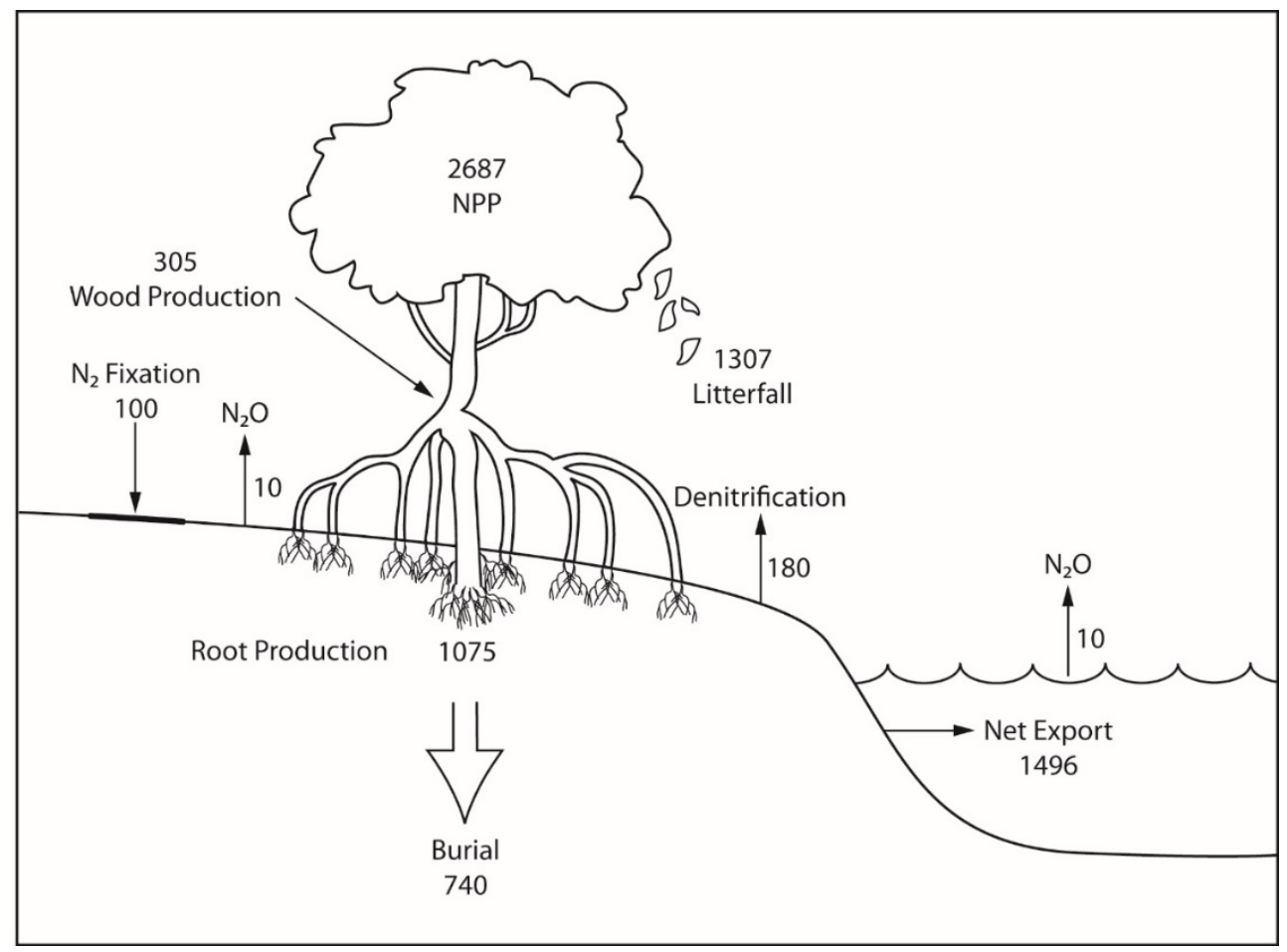

Figure 1. Nitrogen mass balance for the world's mangrove ecosystems. Units are $\mathrm{Gg} \mathrm{N}$ year ${ }^{-1}$. $\mathrm{NPP}=$ net primary production. The model assumes a global mangrove area of $152,000 \mathrm{~km}^{2}$ [2]. Data modified from Alongi [19].

\section{Construction of Impoundments and Deforestation}

Two of the most devastating impacts on mangrove ecosystems are deforestation and the construction of impoundments. Impoundments involve the enclosure of mangroves for the purpose of limiting the movement of water to control problems such as insect infestations, e.g., mosquitoes. Impounding mangroves involves the alteration and disturbance of soil horizons and subsequent change in soil biogeochemistry and geochemistry.

Deforestation is occurring at a rate of about $1 \%$ to $2 \%$ of total area per year [2]. The loss of trees results in the decline of forests but, in the process of cutting trees, the soil horizons are greatly disturbed, which results in the loss of soil and changes in rates and pathways of soil microbial processes. In deforested mangrove soils, concentrations of porewater ammonium are high due to lack of uptake by tree roots but nitrogen fixation rates are low, which suggests surface soil disturbance [20-23]. Removal of mangroves results in equivalent removal of reactive nitrogen [24] as well as an increase in dissolved inorganic nitrogen concentrations in tidal creeks due to drainage of degraded mangroves [25]. The few 
data available also indicate that concentrations of soluble reactive phosphate are lower in deforested areas due to changes in soil geochemistry [26].

Nitrogen transformation processes such as denitrification decline in impounded and cleared forests due to surface disturbance of the soil $[23,27]$. In impounded forests where nitrate was added over a two-year period, the responses of mangroves were insignificant or minor when compared with microbial responses [27]. Denitrification rates increased significantly and nitrous oxide emissions were nearly six times higher in fertilized plots. Nitrogen fixation was lower in fertilized plots. These results suggest that nitrogen-limited impounded mangroves are likely to be long-term sinks for any increases in nitrogen loading [28]. In impoundments where alteration of hydrology results in increased seasonal flooding, the waterlogged soil shows higher soil ammonium, lower nitrate, and lower nitrification and denitrification while plant growth and nitrogen uptake increased especially in dwarf and sparse forest types [23].

More stressful physicochemical conditions result from either incomplete tidal flushing or excessive removal (export) of debris and surface soil due to hydrologic alteration [29]. Local or regional factors such as the salinity regime act together with forest history to control turnover rates of organic matter including soil nitrogen.

\section{Land-Use Change}

Changes in land-use in coastal watersheds is increasingly resulting in rises in inputs of up-river sediments and associated nutrients to mangrove forests. These changes are most often due to poor land practices and deforestation and subsequent erosion of forest soil horizons. While sediment and nutrient enrichment can result in an increase in mangrove mortality [30], such changes can also result in the enhancement of mangrove growth and photosynthesis. The net positive or net negative result likely depends on the amount of sediment and nutrient loading.

Mangroves receiving higher than normal nutrient and sediment loads tend to accumulate organic matter with high rates of sediment accumulation [31]. In an impacted mangrove forest in Brazil, for example, Sanders et al. [31] found that organic carbon and total nitrogen stable isotopes reflect an increased presence of organic matter originating with either phytoplankton, benthic algae, or other allochthonous source within the more rapidly accumulated sediments. This result suggests that the accumulation of organic matter in impacted mangroves may be enhanced through the addition of autochthonous and allochthonous organic matter.

Land-use change resulting in eutrophication may negatively affect mangrove forests by modifying internal carbon and nutrient cycling. Litter decomposition exerts a strong influence on these processes and is potentially modified by eutrophication. In a long-term experiment with nutrient fertilization, Keuskamp et al. [32] found that decomposers were always nitrogen-limited regardless of the effects on the net production of the trees, which leads to a differential nutrient limitation between decomposers and mangroves where the forests were phosphorus-limited. In these latter stands, phosphorus fertilization caused a change in litter quality, which resulted in higher rates of decomposition.

Eutrophication often results in higher rates of nitrogen transformation in mangroves. Weng et al. [33] found that ammonium and nitrate addition resulted in faster rates of ammonification and denitrification from mangrove soils. Furthermore, nitrogen additions change the composition of root exudates. Maher et al. [34] observed that pristine mangrove waters are a sink of nitrous oxide but noted that measurements in impacted mangroves suggest that mangrove waters are a source of nitrous oxide. Thus, eutrophication appears to change mangrove waters from a sink to a source of nitrous oxide to the atmosphere, which represents a "positive feedback to climate change."

Reduction in freshwater flow also results in significant changes in mangrove nutrient cycles. For instance, in the southern Everglades and Florida Bay which have experienced a nearly $50 \%$ reduction in freshwater flow resulting in increased salinity and landward expansion of the mangrove forest [35], soils showed uptake of soluble reactive phosphorus, dissolved organic carbon and nitrite + nitrate, and release of ammonium to the overlying tidal water. Enrichment of phosphorus 
had no effect on dissolved inorganic nitrogen or dissolved organic carbon flux, which suggests that rapid phosphorus uptake may be geochemically mediated with the potential for the mangroves to sequester phosphorus.

Eutrophication impacts on mangroves can be complex and influenced by such factors as tidal inundation frequency, intertidal position, soil type and texture, salinity, and species composition. In fertilization experiments along latitudinal and tidal gradients, Feller et al. [36] found that patterns of nutrient limitation and primary productivity varied by tidal zone and latitude. Nutrient enrichment had complex effects on nutrient conservation with the addition of nutrients having dramatic effects on growth and nutrient recycling even though the pattern "depended on location, site characteristics, and the nature of nutrient limitation." Rates of nutrient transformation vary in pristine and impacted mangroves depending on factors such as the degree of tidal inundation frequency, tidal position, and soil and nutrient input. Reis et al. [37], for example, found that fringe forests exhibit higher rates of nitrogen transformation than basin forests and this, undoubtedly, will hold true if the mangroves were affected by a land-use change.

Ultimately, the effects of land-use change and the resulting eutrophication will likely lead to changes in rates and pathways of nutrient transformation processes in mangroves. These effects will likely, in turn, affect rates of net primary productivity and survival of specific mangrove species. Clearly, more data are needed regarding the effects of eutrophication on soil-plant relationships in relation to global change.

\section{Increased Frequency and Intensity of Storms}

Climate change predictions are for the increased frequency and intensity of storms especially in the wet tropics. Arid regions will become more arid [38]. The impacts of such disturbances on mangroves can be gleaned from studies on the impacts of floods and cyclones (hurricanes, typhoons) on mangrove structure and function. Intense storms can have deleterious effects of mangrove forests especially on canopy structure. What effect such disturbances have on nutrient cycling and the relationship between soil nutrients and mangrove productivity is poorly understood.

Intense storms and flooding may relieve nutrient limitation in mangroves [39]. Tropical cyclones usually result in pulses of freshwater and sediments delivered in floodwaters to the coastal zone. In arid regions, these pulses may be particularly important for the maintenance of mangrove productivity. On the arid coast of Western Australia, Lovelock et al. [39] found that growth of trees was enhanced by a cyclone and nutrient limitation was eased by sediment and associated nutrients delivered by the cyclone. In addition, before the cyclone, the efficiency of resorption of phosphorus and nitrogen from senescent leaves was higher than after the cyclone, which suggests an enhancement of nutrient availability. In impounded mangroves subject to increased summer flooding, there was higher soil ammonium, lower soil nitrate, and lower nitrification and denitrification due to intense soil disturbance [23]. Therefore, mangroves disturbed by impoundments and land-use change will likely be severely impacted by increased storm frequency and intensity.

Monsoons play an important role in mangrove seasonality and this is likely to increase in importance with increasing precipitation. For instance, denitrification is lowest during the monsoon season when compared with pre-monsoon and post-monsoon periods [40]. The influence of limiting substrates is most important during the monsoon season and post-monsoon season. Soil disturbance is likely to be the main cause of the lower denitrification rates due to lower salinity and dilution of soil porewater solutes.

Flooding has been found to affect soil extractable phosphate in mangroves, which, in turn, affects mangrove nutrient limitation and availability [41]. In mangroves of the Bragança Peninsula, North Brazil, patterns of soil redox and soil extractable phosphate confirmed that both parameters are greatly influenced by flooding. Under waterlogged, flooded conditions, there was a net release of extractable phosphate due to reduction-induced solubilization of $\mathrm{P}-\mathrm{Fe} / \mathrm{Al}$ and increased phosphorus availability for trees. Variations in redox and extractable phosphate were reflected in patterns of leaf 
phosphorus concentrations. The forest structure appeared to be influenced by waterlogged conditions, pore water salinity, and phosphorus dynamics. Phosphorus availability plays an important role in controlling mangrove species distributions even though comparatively few data exist on this topic. Thus, disturbances to the nutrient dynamics of mangrove ecosystems by increased frequency and intensity of storms may have a significant effect on mangrove community structure and photosynthesis.

\section{Increasing Temperatures}

The planet is being subject to increasing temperatures and this trend is predicted to continue in forthcoming decades and into the next century [38]. Mangroves will respond similarly to other organisms following a sigmoid curve in which an initial rapid rise in physiological processes (e.g., growth rate, respiration) slows, plateaus, and then declines when a critical lethal threshold is reached and then exceeded [10]. Presumably, mangroves and their associated food webs respond so, but the critical temperatures at which organisms exceed the functional threshold and die are likely $>33^{\circ} \mathrm{C}[10,42]$. Photosynthetic rates for most mangrove species peak at temperatures at or below $30^{\circ} \mathrm{C}$. $\mathrm{CO}_{2}$ assimilation rates of many species decline sharply or gradually when the temperature increases from $33^{\circ} \mathrm{C}$ to $35^{\circ} \mathrm{C}$ [42]. Photo-inhibition often depresses photosynthesis since mid-day declines have been observed, which ensures the survival of leaf photochemical machinery.

Increases in temperature are likely to result in faster growth, reproduction, photosynthesis and respiration, changes in community composition, diversity, and a poleward expansion of latitudinal limits $[43,44]$. Mangroves are currently expanding into higher latitudes in North America, New Zealand, Australia, Southern Africa, and Southern China. This global expansion is most likely the result of increases in mean sea surface temperatures. Expansion of mangroves at the expense of salt marshes is the net result of complex ecological interactions [44]. Mangrove expansion results in more carbon, nitrogen, and phosphorus storage in soils and above-ground and below-ground biomass than in the salt marshes they are displacing, which suggests greater nutrient retention with rising temperatures $[43,44]$.

Temperature increases are likely to result in faster rates of nutrient cycling including rates of soil nitrogen and phosphorus transformation processes. Microbial growth and rates of transformation processes are closely and positively linked to changes in temperature [45]. However, it is unlikely that nutrient-use efficiency is tightly linked to temperature since photosynthetic efficiency likely asymptotes at temperatures below $33^{\circ} \mathrm{C}[10,18]$. Tropical organisms including plants are closer to their upper thermal thresholds than boreal and temperate organisms and are, thus, more vulnerable to increases in temperature.

\section{Increasing Atmospheric $\mathrm{CO}_{2}$}

Higher atmospheric $\mathrm{CO}_{2}$ concentrations can result in increased growth of mangroves even though the responses are species-specific. Species' responses are confounded by variations in salinity, nutrient availability, and water-use efficiency [46-49]. Laboratory data show that mangrove responses in most instances will be complex with some species thriving while others decline or exhibit no or little change.

The coastal location may be an important determinant in the mangrove response given the interactive effects of increased $\mathrm{CO}_{2}$ with salinity and nutrient availability. Based on the ability of each species to respond to spatial and temporal differences in drivers such as salinity and nutrient availability in relation to increasing $\mathrm{CO}_{2}$ levels, species patterns within estuaries may change.

Nutrient availability will vary in relation to frequency of tidal inundation, soil type, and texture as well as soil accretion rates and the geochemical and biogeochemical composition of dissolved and particulate nutrients and other compounds such as sulfides and iron oxide complexes [14,15]. The inputs of nutrients ultimately depend on the accumulation of nutrient elements from the land and the sea. Transformation of organic nitrogen to ammonium via ammonification and release of phosphate and dissolved organic phosphorus are similarly dependent on microbial breakdown of extractable phosphorus compounds [15]. 
Nutrient availability and cycling are unlikely to be directly affected by increases in atmospheric $\mathrm{CO}_{2}$ but will probably be affected depending on the response of mangrove species. Enhanced growth of mangroves will likely result in increased utilization of nutrients such as ammonium and phosphate, which results in more rapid cycling of these essential elements [10,42]. Experiments by Reef et al. [49] show that the effects of $\mathrm{CO}_{2}$ on mangrove growth are more greatly enhanced in the presence of additional nutrients, which is high nutrient availability. Conversely, a decline in mangrove growth will probably translate into decreased utilization and a possible buildup of dissolved soil nutrients, which is similar to the buildup of soil ammonium when mangroves are deforested [12]. Most nitrogen and phosphorus will likely remain immobilized.

\section{Rising Sea-Level}

Sea levels are rising due to thermal expansion of the oceans and the melting of polar and land ice due to increasing temperatures [50]. The rise in the sea level is not uniform due to differences in water density due to varying sea temperatures and the weight of ice sheets as well as water buildup. Mangroves have had to adjust to rises and falls in the sea level since the sea level has waxed and waned over geological time in relation to alternating periods of warming and glaciation [51].

Mangrove surface elevation relative to the sea level is affected by several local and regional short-term and long-term processes. These include subsidence, eustatic changes in the sea level, isostatic changes, changes in the subsurface volume of fluids, accretion of fine sediment particles, litter, algal mats, erosion, subsurface expansion due to root growth, subsidence due to compaction, and drainage of pore water and microbial decomposition [51]. How mangroves may change in relation to the rates of the sea level rise depends greatly on differences in the rates of soil accretion and tectonic uplifting or subsidence [52]. Terrestrial plants will invade from landwards as the mangrove forest recedes, but intertidal mud and sand flats will likely continue to accrete if mangrove forest growth rises at a rate exceeding the local rate of the sea level rise. Conversely, the forest will likely survive if the rate of soil accretion equals the rate of a sea level rise. If the rate of soil accretion is slower than the rate of the sea level rise, the forest will probably drown seawards but invade land newly flushed by tides. Because of local geomorphological features, actual changes may deviate from these scenarios especially in the face of severe storms that may affect short-term rates of the sea level.

The existence of relic pollen and peat deposits suggests that mangroves have undergone dramatic changes due to changes in the sea level. The geological record and present distribution of mangroves indicate that they have survived past changes in the sea level [51]. Peat deposits indicate that mangroves have not kept pace with a sea level rise since the rate of the sea level increased beyond a critical threshold at which mangroves were not able to keep up. Modern evidence indicates that mangrove responses to a sea level rise corresponds roughly to patterns of a surface elevation change. López-Medellin et al. [53] found, for example, that, along the Pacific coast of Mexico, a rise in the sea level due to warm waters of El Niño have drowned mangroves fringing the shore but has resulted in a net increase in mangroves being driven inland. Whether or not mangroves will survive in a given locale depends on local factors such as geomorphology, which makes it difficult to offer simple prognostications on survival or loss. However, there are two regions where survival will be difficult, which includes river deltas and low islands. On low islands in the Pacific, mangroves are being drowned due to a lack of sediment input and due to landward expansion being obstructed because of coastal development. In many deltas of large tropical rivers, subsidence, which is a decline in sediment input due to damming and sea-level rise, storms, and cyclones enhance subsidence. This results in a shift of mangroves landwards but with a net contraction. An analysis of the soil accretion rate versus the rise on a mean sea level shows that roughly half the world's mangroves will not easily survive unless they can invade landwards [7].

Mangroves vary greatly in how they respond to a sea level rise and the effect of tidal flooding and such responses appear to be species-specific [52]. For example, Avicennia marina is highly tolerant to prolonged water logging, but responses are highly variable in relation to the water depth of immersion 
and the length of time as well as salinity, temperature, and other environmental factors [54,55]. There may be other biological responses of mangroves to waterlogging. Mangroves have been shown to exhibit differences in morphology and anatomy in relation to global change. Leaf anatomy, vascular vessel densities, diameter, grouping and length, and fiber wall thickness in a large number of species are affected by waterlogging and salinity. Avicennia marina and Laguncularia racemosa L. also demonstrate modified bark anatomy in response to prolonged flooding as well as the formation of hypertrophied lenticels, adventitious roots, and increased aerenchyma development in the bark. Undoubtedly, there are physiological adaptations to prolonged waterlogging that have direct relevance to a sea level rise.

If the rate of soil accretion and uplift does not keep pace with the sea level rise, seaward mangroves will likely drown and high intertidal mangroves are predicted to progress landwards assuming that space permits [51]. In this scenario, there are likely to be drastic changes in nutrient dynamics including exchange with coastal seas and land. Drowning of seaward mangroves will result in the formation of peat deposits. Once available nutrients are exhausted and trees are dead. These peat deposits will result in a net burial of large amounts of refractory dissolved and particulate nitrogen and phosphorus and other nutrient elements, but no net exchange with the land and the sea [56]. The survival of inland mangroves will be enhanced once frequency of tidal inundation increases with an enhancement of rates of nutrient cycling with an increase in tidal wetting. Wetting will likely result in an increase in $\mathrm{N}_{2} \mathrm{O}$ emissions and an increase in transformation rates of nitrogen such as ammonification, nitrification, and denitrification [23]. In degraded mangroves, Weis et al. [57] found that seaward mangroves still not covered by a sea level rise received their nitrogen and phosphorus supply from nitrogen fixation and phosphorus import from the sea while landward mangroves increasingly covered their nitrogen and phosphorus demand from allochthonous sources and recycling of soil organic matter. Such differences are likely to hold true for mangroves subject to a sea level rise even though there will continue to be large spatial and temporal variations in emissions and rates of dissolved and particulate nutrient flux. For example, inland mangroves that are newly and more frequently wetted by rising tides would be expected to initially export comparatively large amounts of litter that built up on the dry forest floor. Similarly, there will be large litter losses from drowned forests. Gaseous nitrogen fluxes $\left(\mathrm{N}_{2} \mathrm{O}\right.$ and nitrogen fixation) will probably be the greatest during a low tide when soils are exposed in inland mangroves.

Mangroves growing on peat deposits show severe phosphorus limitation [58]. Low phosphorus availability is associated with reduced remobilization of nitrogen and accumulation of potassium in senescent leaves. Remobilization of nitrogen and phosphorus indicate complete resorption before leaf abscission. Peat deposits are, thus, poor substrates for regrowth of mangroves, which means it is unlikely that newly formed peat deposits during a sea level rise will result in any significant growth of marine plants including microalgae or waterlogged mangroves or significant transformation of nutrients via microbial growth. Only a small fraction of nitrogen will be lost from the peat deposits to adjacent tidal waters [59].

In areas where mangroves are slowly drowning such as in the Sundarbans, living forests still act as a sink for atmospheric nitrogen and water column dissolved inorganic nitrogen [60]. The nitrogen stored by plant uptake of $\mathrm{NO}_{\mathrm{x}}, \mathrm{NH}_{3}$ from the atmosphere, nitrogen fixation, and sediment-water exchange are about twice as large as that of recycled nitrogen from litter and could account for $74 \%$ of the nitrogen required for net production. Most nitrogen is conserved in living biomass rather than in soil. Sundarbans mangroves generally conserve nitrogen but conserve only $0.2 \%$ of the annual river flux of nitrogen. Eventual loss of these mangroves to a sea level rise will likely result in little conservation of nitrogen since most nitrogen in biomass will be lost as floating debris to the adjacent coastal ocean.

\section{Predictions}

In pristine mangroves, the largest inputs of nitrogen are soil ammonification, nitrification, uptake of dissolved inorganic nitrogen via tides, and dissimilatory nitrate reduction to ammonium while 
the largest loss of nitrogen is through tidal export. Global change impacts on these processes are predicted to affect nutrient cycling and mangrove productivity. Like tides, the impacts of global change on mangroves wax and wane. Some impacts are predicted to have deleterious consequences on nutrient cycles and, thus, on forest productivity. Other impacts are expected to have positive effects on nutrient cycles and production while some impacts are unlikely to have any clear effects on mangrove ecosystems. Deforestation and changes in hydrology in the construction and maintenance of impoundments have severe consequences for mangrove survival (Table 1). Subsequent formation of peat deposits implies that subsequent mangroves will be dwarf forests due to peat being a poor substrate for growth.

Table 1. Impacts of global change on mangrove nutrient cycling. " + " = stimulatory, "-" = deleterious.

\begin{tabular}{ccc}
\hline Disturbance & Nitrogen Cycling & Phosphorus Cycling \\
\hline Deforestation/Construction of Impoundments & - & - \\
Land-Use Change & +- & +- \\
Increased Frequency/Intensity of Storms & +- & +- \\
Increasing Temperatures & + & + \\
Increasing Atmospheric CO & + & + \\
Rising Sea Level & +-0 & +-0 \\
\hline
\end{tabular}

Some land-use changes such as additional inputs of sediment and nutrients will probably have positive effects on mangrove nutrient cycles while some changes such as eutrophication will have negative consequences (Table 1). The same holds true for increased frequency and intensity of storms. Increases in rainfall in arid-zone areas are predicted to relieve nutrient limitation and enhance mangrove growth while more severe tropical cyclones will likely have negative effects. Increasing temperatures and atmospheric $\mathrm{CO}_{2}$ concentrations are predicted to initially have positive consequences for nutrient cycles and mangrove productivity even though more data are needed to properly assess their effects. The effects of a rising sea level are complex likely due to both positive and negative consequences depending on several co-factors such as the rates of subsidence, the soil accretion rate, and the tidal position. If soil accretion rates and uplift keep pace with a rise in the sea level, there may be no clear impacts on nutrient cycling and mangrove forest structure and function. If accretion and uplift do not keep pace, seaward mangroves will drown but high intertidal mangroves will likely progress landwards assuming space is available.

At present, there are still substantial limitations to our knowledge of the impacts of global change on mangroves and their relationships with nutrients. More data are needed on the impacts of various scenarios of a sea level rise on mangrove-nutrient relations as well as the impacts of the increased frequency and intensity of storms. Future research should focus on development of experimental approaches to test the effects of these global impacts on mangrove-nutrient relations, as most data is descriptive.

Funding: This research received no external funding.

Conflicts of Interest: The author declares no conflict of interest.

\section{References}

1. Alongi, D.M. Present state and future of the world's mangrove forests. Environ. Conserv. 2002, 29, 331-349. [CrossRef]

2. Spalding, M.M.; Kainuma, M.; Collins, L. World Atlas of Mangroves; Earthscan: London, UK, 2010; pp. 1-302, ISBN 1844076571.

3. Saenger, P. Mangrove Ecology, Silviculture and Conservation; Kluwer: Dordrecht, The Netherlands, 2002; pp. 1-360.

4. Alongi, D.M. The Energetics of Mangrove Forests; Springer: Dordrecht, The Netherlands, 2009; pp. 1-216, ISBN 978-1-4020-4270-6. 
5. Alongi, D.M. Carbon cycling and storage in mangrove forests. Ann. Rev. Mar. Sci. 2014, 6, $195-219$. [CrossRef] [PubMed]

6. Alongi, D.M. Mangrove forests: Resilience, protection from tsunamis, and responses to global climate change. Estuar. Coast. Shelf Sci. 2008, 76, 1-13. [CrossRef]

7. Alongi, D.M. The impact of climate change on mangrove forests. Curr. Clim. Chang. Rep. 2015, 1, 30-39. [CrossRef]

8. Gilman, E.L.; Ellison, J.; Duke, N.C.; Field, C. Threats to mangroves from climate change and adaptation options: A review. Aquat. Bot. 2008, 89, 237-250. [CrossRef]

9. Reef, R.; Feller, I.C.; Lovelock, C.E. Nutrition of mangroves. Tree Physiol. 2010, 30, 1148-1160. [CrossRef]

10. Ball, M.C. Ecophysiology of mangroves. Trees 1988, 2, 129-142. [CrossRef]

11. Alongi, D.M. Dissolved iron supply limits early growth of estuarine mangroves. Ecology 2010, 91, 3229-3241. [CrossRef]

12. Alongi, D.M. Micronutrients and mangroves: Experimental evidence for copper limitation. Limnol. Oceangr. 2017, 62, 2759-2772. [CrossRef]

13. Lovelock, C.E.; Feller, I.C.; Ball, M.C.; Engelrecht, B.M.J.; Ewe, M.L. Differences in plant function in phosphorus- and nitrogen-limited mangrove ecosystems. New Phytol. 2006, 172, 514-522. [CrossRef]

14. Alongi, D.M.; Boto, K.G.; Robertson, A.I. Nitrogen and phosphorus cycles. In Tropical Mangrove Ecosystems; Robertson, A.I., Alongi, D.M., Eds.; American Geophysical Union: Washington, WA, USA, 1992; pp. 251-292, ISBN 0-87590-255-3.

15. Sherman, R.E.; Fahey, T.J.; Howarth, R.W. Soil-plant interactions in a neotropical mangrove forest: Iron, phosphorus and sulfur dynamics. Oecologia 1998, 115, 553-563. [CrossRef] [PubMed]

16. Kristensen, E.; Andersen, F.Ø.; Holmboe, N.; Holmer, M.; Thongtham, N. Caron and nitrogen mineralization in sediments of the Bangrong mangrove area, Phuket, Thailand. Aquat. Microb. Ecol. 2000, 22, 199-213. [CrossRef]

17. Alongi, D.M.; Clough, B.F.; Robertson, A.I. Nutrient-use efficiency in mangrove forests along the arid tropical coast of Western Australia. Aquat. Bot. 2005, 82, 121-131. [CrossRef]

18. Lovelock, C.E.; Krauss, K.W.; Osland, M.J.; Reef, R.; Ball, M.C. The physiology of mangrove trees with changing climate. In Tropical Tree Physiology: Adaptations and Responses in a Changing Environment; Goldstein, G., Santiago, L.S., Eds.; Springer: New York, NY, USA, 2016; pp. 149-179.

19. Alongi, D.M. Cycling and global fluxes of nitrogen in mangroves. Glob. Environ. Res. 2013, 17, $173-182$.

20. Alongi, D.M.; de Carvalho, N.A. The effect of small-scale logging on stand characteristics and soil biogeochemistry in mangrove forests of Timor Leste. Forest Ecol. Manag. 2008, 255, 1359-1366. [CrossRef]

21. Vovides, A.G.; López-Portillo, J.; Bashan, Y. $\mathrm{N}_{2}$-fixation along a gradient of long-term disturbance in tropical mangroves bordering the Gulf of Mexico. Biol. Fertil. Soils 2011, 47, 567-576. [CrossRef]

22. Vovides, A.G.; Bashan, Y.; López-Portillo, J.A.; Guevara, R. Nitrogen fixation in preserved, reforested, naturally regenerated and impaired mangroves as an indicator of functional restoration in mangroves in an arid region of Mexico. Restor. Ecol. 2011, 19, 236-244. [CrossRef]

23. Verhoeven, J.T.A.; Laanbroek, H.J.; Rains, M.C.; Whigham, D.F. Effects of summer flooding on nitrogen dynamics in impounded mangroves. J. Environ. Manag. 2014, 139, 217-226. [CrossRef]

24. Jordan, S.J.; Stoffer, J.; Nestlerode, J.A. Wetlands as sinks for reactive nitrogen at continental and global scales: A meta-analysis. Ecosystems 2011, 14, 144-155. [CrossRef]

25. Mandal, S.; Ray, S.; Ghosh, P.B. Impact of mangrove litterfall on nitrogen dynamics of virgin and reclaimed islands of Sundarbans mangrove ecosystem, India. Ecol. Model. 2013, 252, 153-166. [CrossRef]

26. Sjöling, S.; Mohammed, S.M.; Lyimo, T.J.; Kyaruzi, J.J. Benthic bacterial diversity and nutrient processes in mangroves: Impact of deforestation. Estuar. Coast. Shelf Sci. 2005, 63, 397-406. [CrossRef]

27. Whigham, D.F.; Verhoeven, J.T.A.; Samarkin, V.; Megonigal, P.J. Responses of Avicennia germinans (black mangrove) and the soil microbial community to nitrogen addition in a hypersaline wetland. Estuar. Coasts 2009, 32, 926-936. [CrossRef]

28. Feller, I.C.; Whigham, D.F.; McKee, K.L.; Lovelock, C.E. Nitrogen limitation of growth and nutrient dynamics in a disturbed mangrove forest, Indian River Lagoon, Florida. Oecologia 2003, 134, 405-414. [CrossRef]

29. McKee, K.L.; Faulkner, P.L. Restoration of biogeochemical function in mangrove forests. Restor. Ecol. 2000, 8 , 247-259. [CrossRef] 
30. Lovelock, C.E.; Ball, M.C.; Martin, K.C.; Feller, I.C. Nutrient enrichment increases mortality of mangroves. PLoS ONE 2009, 4, e5600. [CrossRef]

31. Sanders, C.J.; Eyre, B.D.; Santos, I.R.; Machado, W.; Luiz-Silva, W.; Smoak, J.M.; Breithaupt, J.L.; Ketterer, M.E.; Sanders, L.; Marotta, H.; et al. Elevated rates of organic carbon, nitrogen, and phosphorus accumulation in a highly impacted mangrove wetland. Geophys. Res. Lett. 2014, 41, 2475-2480. [CrossRef]

32. Keuskamp, J.A.; Hefting, M.M.; Dingemans, B.J.J.; Verhoeven, J.T.A.; Feller, I.C. Effects of nutrient enrichment on mangrove leaf litter decomposition. Sci. Total Environ. 2015, 508, 402-410. [CrossRef] [PubMed]

33. Weng, B.; Xie, X.; Yang, J.; Liu, J.; Lu, H.; Yan, C. Research on the nitrogen cycle in rhizosphere of Kandelia obovata under ammonium and nitrate addition. Mar. Pollut. Bull. 2013, 76, 227-240. [CrossRef]

34. Maher, D.T.; Sippo, J.Z.; Tait, D.R.; Holloway, C.; Santos, I.R. Pristine mangrove creek waters are a sink for nitrous oxide. Sci. Rep. 2016, 6, 25701. [CrossRef]

35. Liu, K.J.; Li, H.P.; Davis S.E., III. Benthic exchange of C, N, and P along the estuarine ecotone of Lower Taylor Slough, Florida (USA): Effect of seasonal flows and phosphorus availability. Wetlands 2014, 34, 113-122. [CrossRef]

36. Feller, I.C.; Lovelock, C.E.; Piou, C. Growth and nutrient conservation in Rhizophora mangle in response to fertilization along latitudinal and tidal gradients. Smithson. Contrib. Mar. Sci. 2009, 38, 345-358.

37. Reis, C.R.G.; Nardoto, G.B.; Rochelle, A.L.C.; Vieira, S.A.; Oliveira, R.S. Nitrogen dynamics in subtropical fringe and basin mangrove forests inferred from stable isotopes. Oecologia 2017, 183, 841-848. [CrossRef] [PubMed]

38. Collins, M.; Knutti, R.; Arblaster, J.; Dufresne, J.-L.; Fichefet, T.; Friedlingstein, P.; Gao, X.; Gutowski, T.; Johns, T.; Krinner, G.; et al. Long-term climate change: Projections, commitments and irreversibility. In Climate Change 2013: The Physical Basis, Contribution of Working Group I to the Fifth Assessment Report of the Intergovernmental Panel of Climate Change; Stocker, T.F., Qin, D., Plattner, G.-K., Tignor, M., Allen, S.K., Boschung, J., Nauels, A., Xia, Y., Bex, V., Midgley, P.M., Eds.; Cambridge University Press: Cambridge, UK, 2013; pp. 1029-1136.

39. Lovelock, C.E.; Feller, I.C.; Adame, M.F.; Reef, R.; Penrose, H.M.; Wei, L.; Ball, M.C. Intense storms and the delivery of materials that relieve nutrient limitations in mangroves of an arid zone estuary. Funct. Plant Biol. 2011, 38, 514-522. [CrossRef]

40. Fernandes, S.O.; Gonsalves, M.-J.; Michotey, V.D.; Bonin, P.; Loka Bharathi, P.A. Denitrification activity is closely linked to the total ambient Fe concentration in mangrove sediments of Goa, India. Estuar. Coast. Shelf Sci. 2013, 131, 64-74. [CrossRef]

41. Mendoza, U.N.; da Cruz, C.C.; Menezes, M.P.; Lara, R.J. Flooding effects on phosphorus dynamics in an Amazonian mangrove forest, Northern Brazil. Plant Soil 2012, 353, 107-121. [CrossRef]

42. Ball, M.C.; Sobrado, M.A. Ecophysiology of mangroves: Challenges in linking physiological processes with patterns of forest structure. In Physiological Plant Ecology; Scholes, J.C., Press, M., Barker, M.G., Eds.; Blackwell: Oxford, UK, 2002; pp. 331-346, ISBN 0521549299.

43. Cavanaugh, K.C.; Kellner, J.R.; Forde, A.J.; Gruner, D.S.; Parker, J.D.; Rodriguez, W.; Feller, I.C. Poleward expansion of mangroves is a threshold response to decreased frequency of extreme cold events. Proc. Nat. Acad. Sci. USA 2014, 111, 723-727. [CrossRef]

44. Saintilan, N.; Wilson, N.; Rogers, K.; Rajkaran, A.; Krauss, K.W. Mangrove expansion and salt marsh decline at mangrove poleward limits. Glob. Chang. Biol. 2014, 20, 147-157. [CrossRef]

45. Alongi, D.M. Bacterial production and microbial biomass in tropical mangrove sediments. Microb. Ecol. 1988, 15, 59-79. [CrossRef]

46. Farnsworth, E.J.; Ellison, A.M.; Gong, W.K. Elevated $\mathrm{CO}_{2}$ alters anatomy, physiology, growth, and reproduction of red mangrove (Rhizophora mangle L.). Oecologia 1996, 108, 599-609. [CrossRef]

47. Ball, M.C.; Cochrane, M.J.; Rawson, H.M. Growth and water use of the mangroves Rhizophora apiculata and $R$. stylosa in response to salinity and humidity under ambient and elevated concentrations of atmospheric $\mathrm{CO}_{2}$. Plant Cell Environ. 1997, 20, 1158-1166. [CrossRef]

48. McKee, K.L.; Rooth, J.E. Where temperate meets tropical: Multifactorial effects of elevated $\mathrm{CO}_{2}$, nitrogen enrichment, and competition on a mangrove-salt marsh community. Glob. Chang. Biol. 2008, 14, 971-984. [CrossRef] 
49. Reef, R.; Slot, M.; Motro, U.; Motro, Y.; Adame, M.F.; Garcia, M.; Aranda, M.F.; Lovelock, C.E.; Winter, K. The effects of $\mathrm{CO}_{2}$ and nutrient fertilization on the growth and temperature response of the mangrove Avicennia germinans. Photosynth. Res. 2016, 129, 159-170. [CrossRef] [PubMed]

50. Church, J.A.; Clark, P.U.; Cazenave, A.; Gregory, J.M.; Jevrejeva, S.; Levermann, A.; Merrifield, M.A.; Milne, G.A.; Nerem, R.S.; Nunn, P.D.; et al. Sea level change. In Climate Change 2013: The Physical Basis, Contribution of Working Group I to the Fifth Assessment Report of the Intergovernmental Panel of Climate Change; Stocker, T.F., Qin, D., Plattner, G.-K., Tignor, M., Allen, S.K., Boschung, J., Nauels, A., Xia, Y., Bex, V., Midgley, P.M., Eds.; Cambridge University Press: Cambridge, UK, 2013; pp. 1137-1216.

51. Woodroffe, C.D.; Rogers, K.; McKee, K.L.; Lovelock, C.E.; Mendelssohn, I.A.; Saintilan, N. Mangrove sedimentation and responses to relative sea-level rise. Annu. Rev. Mar. Sci. 2016, 8, 243-266. [CrossRef] [PubMed]

52. Krauss, K.W.; McKee, K.L.; Lovelock, C.E.; Cahoon, D.R.; Saintilan, N.; Reef, R.; Chen, L. How mangrove forests adjust to rising sea level. New Phytol. 2013, 202, 19-34. [CrossRef] [PubMed]

53. López-Medellin, X.; Ezcurra, E.; González-Abraham, C.; Hak, J.; Santiago, L.S.; Sickman, J.O. Oceanographic anomalies and sea-level rise drive mangroves inland in the Pacific coast of Mexico. J. Veget. Sci. 2011, 22, 143-151. [CrossRef]

54. Lu, W.; Chen, L.; Wang, W.; Tam, N.F.-Y.; Lin, G. Effects of sea level rise on mangrove Avicennia population growth, colonization and establishment: Evidence from a field survey and greenhouse manipulation experiment. Acta Oecol. 2013, 49, 83-91. [CrossRef]

55. Mangora, M.M.; Mtolera, M.S.P.; Björk, M. Photosynthetic responses to submergence in mangrove seedlings. Mar. Freshw. Res. 2014, 65, 497-504. [CrossRef]

56. Parkinson, R.W.; DeLaune, R.D.; White, J.R. Holocene sea-level rise and the fate of mangrove forests within the wider Caribbean region. J. Coast. Res. 1994, 10, 1077-1086.

57. Weis, C.; Weiss, J.; Boy, J.; Iskandar, I.; Mikutta, R.; Guggenberger, G. Soil organic carbon stocks in estuarine and marine mangrove ecosystems are driven by nutrient colimitation of P and N. Ecol. Evol. 2016, 6, 5043-5056. [CrossRef] [PubMed]

58. Medina, E.; Cuevas, E.; Lugo, A.E. Nutrient relations of dwarf Rhizophora mangle L. mangroves on peat in eastern Puerto Rico. Plant Ecol. 2010, 207, 13-24. [CrossRef]

59. Keukamp, J.A.; Feller, I.C.; Laanbroek, H.J.; Verhoeven, J.T.A.; Hefting, M.M. Short- and long-term effects of nutrient enrichment on microbial exoenzyme activity in mangrove peat. Soil Biol. Biochem. 2015, 81, $38-47$. [CrossRef]

60. Ray, R.; Majumder, N.; Das, S.; Chowdhury, C.; Jana, T.K. Biogeochemical cycle of nitrogen in a tropical mangrove ecosystem, east coast of India. Mar. Chem. 2014, 167, 33-43. [CrossRef] 